\title{
Depression Among Rural Aged : Facts \& Reasons
}

\author{
*M Rahman ${ }^{1}$, A Rahman², TT Sajoni ${ }^{3}$ \\ $1 *$ Prof. Dr. Md. Mahfuzar Rahman, Professor and Head Dept. of Community Medicine, AKMMC \\ ${ }^{2}$ Dr. Md. Atiqur Rahman, Assistant professor, Dept. of Community Medicine, AKMMC

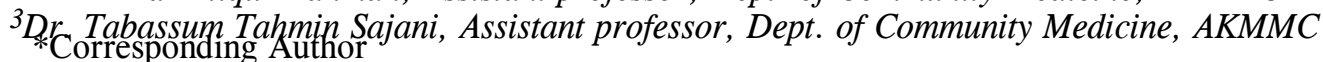

Date of submission: 28 March 2015

Date of acceptance: 02 April 2015

\begin{abstract}
Background: In Bangladesh person aged 60 years or above are considered to elderly. 5.9\% of total population are within the age group of 55-65years and 65 years old or above are 5\% of the total population. Elderly dependency ratio is $7.3 \%$. Depression is a common problem among the older people, but it is not a normal part of aging. The aim of this study was to find out the level of depression, factors associated with depression and health problems among the respondents .

Material and Methods: This descriptive cross sectional study was carried among 829 people aged more than 60 years by purposive sampling technique from 7th to 9th December, 2014 in different vilages of Dhamrai Upazila,Dhaka. Data were collected on a pretested questionnaire by face to face interview using short form of GDS. Data were analyzed manually and by using computer.

Results: Then study revealed that majority of the respondents (82\%) were Muslims by religion. About 39\% respondents were aged more than 70 years and mean age was $68 \pm 3.7$ years. Most of them (52\%) were illiterate and only $5 \%$ had received HSC or higher education. About $15 \%$ respondents' occupation were service and $47 \%$ of the respondents were housewives. Among all the respondents about $22 \% \& 26 \%$ were found to have $2 \& 3$ number of children respectively. About $27 \%$ \& $18 \%$ respondents were suffering from mild \& moderate depression respectively. Feeling burden on others, physical disability, lack of close family ties \& Living alone were found the main factors of depression in $27 \%, 26 \%, 26 \%$ \& $22 \%$ respondents respectively. About $59 \%, 57 \%, 49 \% \& 28 \%$ respondents were suffering from poor vision, musculo-skeletal diseases, hypertension \& chest pain respectively.

Conclusion: Elderly people are suffering from various health problems due to depression. The study findings demand awareness among family members as well as an establishment of comprehensive one stop health care delivery package for the senior citizens.
\end{abstract}

Key words : Elder people, Depression, Geriatric Depression Scale (GDS)

\section{Introduction}

Depression is a common problem among older adults, but it is not a normal part of aging. It may be overlooked because for some older adults who have depression, sadness is not their main symptom. They may have other less obvious symptoms of depression or they may not be willing to talk about their feelings. Therefore doctors may be less likely to recognized that their patient has depression ${ }^{1}$.

Depressive disorder has prevalence of $5 \%$ in the general population and approximately $10 \%$ in chronically ill medical out patients. It is a major cause of disability and of suicide. If comorbid with a medical condition depression magnifies disability, diminishes adherence to medical treatment and rehabilitation and may even shorten life expectancy. Such comorbid depression may incrementally worsen health more than any combination of chronic diseases without depression ${ }^{2}$.

There is ongoing debate as to whether the prevalence 
21 AKMMC J $2015: 6(2)$

of depression increases or decreases with age $^{3}$. It appears that formal diagnoses of depression are less common in older people, with rates considerably lower than those in younger populations ${ }^{4}$. However, when broader measures are used, including those that do not exclude from diagnosing contextual conditions that are more common in older people, such as bereavement or dementia, prevalence rates of between $6 \%$ and $20 \%$ have been reported in communitydwelling populations 5,6 up to $50 \%$ in older people living in residential aged care $^{7}$ and $48 \%$ in a hospital sample 8,9 .

There is genetic predisposition to depression, especially when of early onset. The number and identity of gene are largely unknown but the serotonin transporter gene is candidate. Adversity and emotional deprivation early in life also predispose to depression. Depressive episodes are often triggered by stressful life events (especially those that involve loss), including medical illnesses. Associated biological factors include hypofunction of monoamine neurotransmitter systems (5-HT and noradrenalin) and abnormal hypothalamic-pituitary- adrenal axis regulation which results in elevated cortisol levels that do not suppress with dexamethasone ${ }^{2}$.

Depression is a serious condition for people of all ages, but for older people depression is often associated with other co-morbid conditions, such as physical disability 5,6,8 and anxiety that exacerbate the distress experienced by older people and their carers.

Everyone feels down or sad sometimes, but these feelings usually pass after a few days. Depression makes trouble with daily life for weeks at a time. Depression is a serious illness that needs treatment; if left untreated depression can lead to suicide.

While recognition of older age depression has improved in recent years ${ }^{10}$ there are still gaps in knowledge about assessment and diagnosis for particular population groups ${ }^{6}$.There is also insufficient knowledge about effective treatments for depression amongst older people. There have been a considerable number of drug trials over the past 40 years and since anti-depressant medication has become less toxic, it is therefore more likely to be prescribed for older people ${ }^{10}$. There are fewer studies on psychotherapy although there is evidence that
M Rahman, A Rahman, TT Sajoni

cognitive behavioural approaches are effective with older people . Electro-convulsive therapy (ECT) has been found to be effective with older people who have severe depression6 but the available literature is sparse $^{9}$.

An earlier review conducted in Australia examined mental health research activity against the criteria of disease burden and health system costs and concluded that affective disorders and dementia were particularly under-researched given their contribution to burden of disease and health costs ${ }^{11}$. There is therefore a need for further research into older age depression and anxiety. The purpose of this study is to clarify the direction of future research into older age depression and anxiety in order to set priorities for research conducted by and/or on behalf of beyondblue.

\section{Practice points}

* Majority respondents were suffering from mild to moderate depression.

* Burden on others, Physical disability, Lack of close family ties \& Living alone were the main factors of depression.

* Poor vision, Musculo-skeletal diseases, Hypertension and Chest pain were the major health problems of the respondents.

\section{Methodology}

This was a descriptive cross sectional study carried out in Dhamrai Upazila, Dhaka under Dhamrai union in Taltola, Choibaria, Kumrail, Islampur, Chandrail, Ambagan, Palara and Sadamath villages during the period 7th to 9th December, 2014 for data collection. Individuals aged above 60 years during data collection period were the study population. Total size of the sample was 829 and sampling technique was purposive in nature. Duly pre-tested structured questionnaire in conjunction with Geriatric Depression Scale (GDS) short form was the instruments for data collection. It was collected through face to face interview by 4 th year MBBS students (AKMMC -04) of Anwer Khan Modern Medical College, Dhanmondi, Dhaka with prior filling up a consent form and signed by the respondent as a part of ethical consideration. It was processed and analyzed manually and by using computer. 
Depression Among Rural Aged : Facts \& Reasons

\section{Results}

Table-I Distribution of respondents by Sociodemographic characteristicsn $=829$

\begin{tabular}{|c|c|c|c|}
\hline Characteristics & Categories & Frequency & Perce ntage (\%) \\
\hline \multirow[t]{4}{*}{ Age in years } & $60-65$ & 234 & 28 \\
\hline & $66-70$ & 269 & 33 \\
\hline & $>70$ & 326 & 39 \\
\hline & Total & 829 & 100 \\
\hline \multirow[t]{3}{*}{ Sex } & Male & 402 & 48 \\
\hline & Femæl & 427 & 52 \\
\hline & Total & 829 & 100 \\
\hline \multirow[t]{3}{*}{ Religion } & Muslims & 679 & 82 \\
\hline & Hindus & 150 & 18 \\
\hline & Total & 829 & 100 \\
\hline \multirow[t]{5}{*}{ Level of education } & Illiterate & 429 & 52 \\
\hline & Primary & 235 & 28 \\
\hline & Secondary & 122 & 15 \\
\hline & HSC \&above & 43 & 5 \\
\hline & Total & 829 & 100 \\
\hline \multirow[t]{6}{*}{ Occupation } & Service & 125 & 15 \\
\hline & Business & 101 & 10 \\
\hline & Agriculture & 87 & 12 \\
\hline & House -wife & 186 & 47 \\
\hline & bourer \& others & 129 & 12 \\
\hline & Total & 829 & 100 \\
\hline \multirow[t]{5}{*}{ Monthly income } & $<3000$ & 389 & 47 \\
\hline & $3001-6000$ & 166 & 20 \\
\hline & $6001-9000$ & 92 & 12 \\
\hline & $>9000$ & 183 & 22 \\
\hline & To tal & 829 & 100 \\
\hline \multirow[t]{5}{*}{ Marital status } & Unmarried & 53 & 8 \\
\hline & Married & 607 & 73 \\
\hline & Divorced & 14 & 2 \\
\hline & Widow & 155 & 19 \\
\hline & Total & 829 & 100 \\
\hline
\end{tabular}

Muslims were predominant among the respondents of about $82 \%$ and $48 \%$ respondents were found to have 2 - 3 number of children respectively.
Table II Distribution of respondents by Factors associated with depressionn $=829$

\begin{tabular}{|c|c|c|c|}
\hline Factors & $\begin{array}{l}\text { Number of } \\
\text { respondents }\end{array}$ & Factors & $\begin{array}{l}\text { Number of } \\
\text { respondents }\end{array}$ \\
\hline Being female & $172(21)$ & \multicolumn{2}{|c|}{ Relocation of residence 137 (17) } \\
\hline $\begin{array}{l}\text { Being Single/ } \\
\text { Widowed/ Divor }\end{array}$ & rced $158(19)$ & Physical disability & $212(26)$ \\
\hline $\begin{array}{r}\text { Lack of supporti } \\
\text { social network }\end{array}$ & tive $212(26)$ & \multicolumn{2}{|c|}{ Feeling burden on others222 (27) } \\
\hline $\begin{array}{l}\text { Death of a Spous } \\
\text { Siblings/Friend }\end{array}$ & e/ $161(19)$ & Living alone & $184(22)$ \\
\hline \multirow[t]{2}{*}{ Retirement } & $136(16)$ & \multicolumn{2}{|c|}{ Lack of close family ties214 (26) } \\
\hline & & Don't know & $29(4)$ \\
\hline \multicolumn{2}{|l|}{ Total } & \multicolumn{2}{|c|}{$829(100)$} \\
\hline
\end{tabular}

Feeling burden on others (27); lack of close family ties (26); physical disability (26) and living alone (22) were identified as factors associated with depression.

(N.B: Figures in the parenthesis indicate percentage)

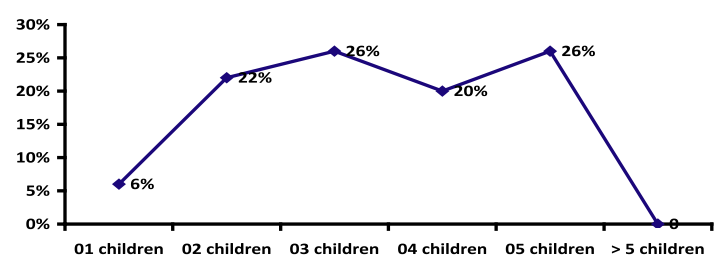

Figure 01 : Line diagram showing distribution of respondents by number of children

$48 \%$ respondents were found having 2-3 number of children .

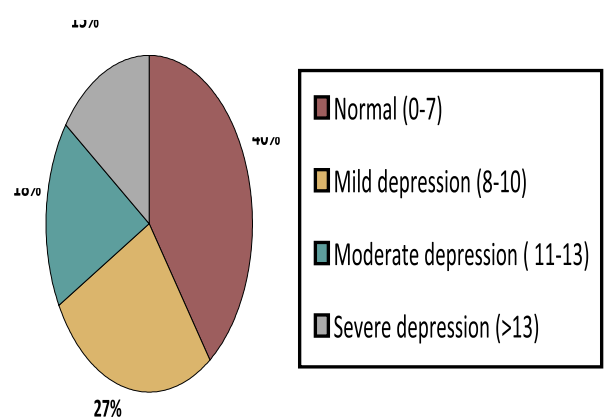

Figure 02 : Pie diagram showing distribution respondents by level of depression

(Based on Geriatric Depression Scale (GDS) short form : 0-13)

About $27 \%$ \& $18 \%$ respondents were suffering from mild and moderate depression respectively. 


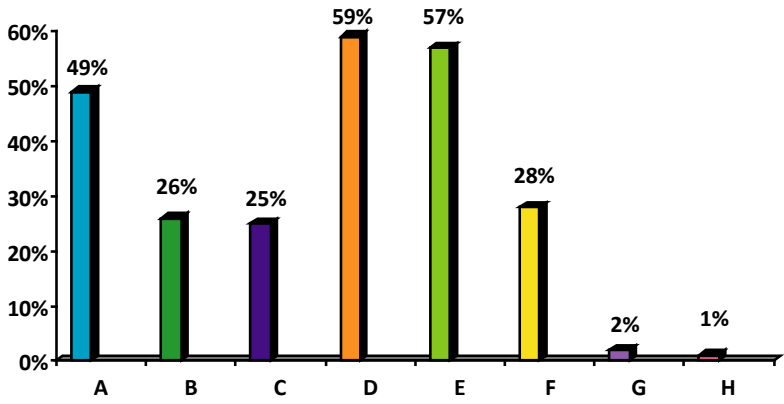

Figure 03: Simple Bar diagram showing distribution of respondents by Health problems

Note:

A- Hypertension E- Musculoskeletal diseases

B- Diabetes Mellitus F- Chest pain

C- Asthma G- Thyroid diseases

D- Poor vision $\mathrm{H}$ - Cancer

About 59\%, 57\%, 49\% \& 28\% respondents were suffering from poor vision, musculoskeletal diseases, hypertension and chest pain respectively.

\section{Discussion}

In this study (52\%) respondents were female and mostly illiterate in particular and less empowered in our society. Majority were having occupation as housewives (47\%). About $27 \%$ \& $18 \%$ respondents were suffering from mild to moderate level of depression. But according to the text book of medicine, the prevalence of depressive disorder is $5 \%$ in general population ${ }^{2}$.

In addition, the study shows feeling burden on others, physical disability, lack of close family ties \& living alone as the factors of depression respectively. Moreover, respondents were having additional health problems like; poor vision, musculoskeletal diseases, hypertension \& chest pain. This findings varies with findings of the survey of a private medical college of Bangladesh which estimated poor vision $48 \%$, hypertension $40 \%$ \& chest pain $50 \%$ 12. This discrepancy might have justified with the fact that the study was conducted with a small sample size within a semi urban community setting.

\section{Conclusion}

The study concludes that most of the respondents were suffering from mild to moderate depression. Geriatric health is an emerging issue in Bangladesh as well as in the world. Physical disability, lack of close family ties were observed as the major factors of depression. In this study major health problems that were noticed among the respondents were poor vision, musculoskeletal disorders \& hypertension.

\section{Recommendations}

The following recommendations may be considered on the basis of this study findings :

* Needs sound relevant awareness program among the family members regarding the factors of depression.

* Provision of early detection and appropriate management of depression associated health problems by family members or physicians.

* Demands a large scale study on depression among the elderly to explore the magnitude or extent of the situation.

* There is a scope for establishment of comprehensive one stop health care delivery package for the senior citizens towards improvement of their health status.

\section{Acknowledgement}

It is the pleasure to acknowledge Principal \& Viceprincipal of Anwer Khan Modern Medical College to support in conducting this study. The department of Community Medicine, AKMMC also gratefully acknowledge the supports and guidance from Director of NIPSOM \& his staffs at Dhamrai THC during our stay at their premises. Thanks to all the lecturers of the Department of Community Medicine and students (AKMMC-04 batch) for their hard work in participating, conducting and implementing this study protocol in particular. Finally, last but not least the people of the study area are gratefully acknowledged for their cooperation and participation as key informants. 


\section{References}

1. Older adults and depression- Good overview of depression in older adults, Fact sheet, National Institute of Mental Health (NIMH), updated , October, 2012, 1-4

2. Nicki R. Colledge, Brian R. Walker, Stuart H. Ralsto, Davidson's Principles and Practice of Medicine; 233.

3. O'Connor, D. W. (2006). Do older Australians truly have low rates of anxiety and depression? A critique of the 1997 National Survey of Mental Health and Wellbeing. Australian and New Zealand Journal of Psychiatry, 40, $623-631$.

4. Australian Bureau of Statistics. (1998). Mental Health and Wellbeing:Profile of Adults, Australia (No. ABS Catalogue No. 4326.0). Canberra: ABS.

5. Baldwin, R. (2008). Mood disorders: depressive disorders. In R. Jacoby, C. Oppenheimer, T. Dening \& A. Thomas (Eds.), Oxford Textbook of Old Age Psychiatry (4th ed.). Oxford: Oxford University Press.

6. Chiu, E., Ames, D., Draper, B., \& Snowdon, J. (1999). Depressive disorders in the elderly: a review. In M. Maj \& N. Sartorius (Eds.), Depressive disorders. Chichester: John Wiley.
7. Cummings, S. M. (2002). Predictors of psychological wellbeing among assisted-living residents. Health \& Social Work, 27, 293-302.

8. Bryant, C., Jackson, H., \& Ames, D. (2008). The prevalence of anxiety in older adults: Methodological issues and a review of the literature. Journal of Affective Disorders, 109, 233-250.

9. Ames, D. (2001). Depression and the elderly. In A. Dawson \& A. Tylee (Eds.), Depression: Social and economic timebomb Strategies for quality care. London: BMJ Books.

10. Llewellyn-Jones, R., \& Snowdon, J. (2007). Depression in nursing homes: ensuring adequate treatment. CNS Drugs, 21(8), 627-640.

11. Jorm, A. F., \& Kelly, C. M. (2007). Improving the public's understanding and response to mental disorders Australian Psychologist, 42, 81 - 89.

12. Geriatric Health Problems in a Rural Community of Bangladesh; Ibrahim Med. Coll. Journal; 2007; 1(2): $12-20$. 